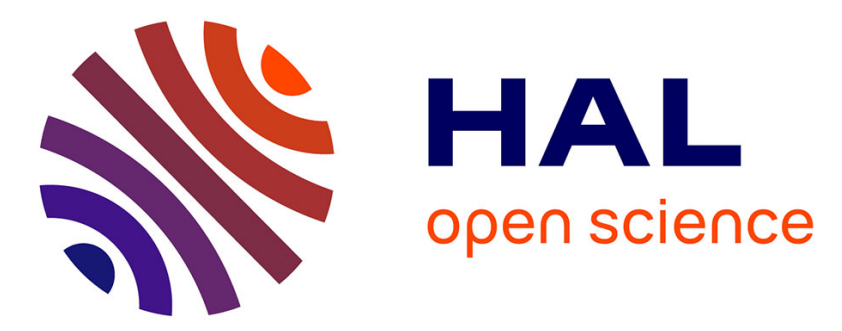

\title{
Influence of the nature and environment of cobalt on the catalytic activity of Co-BEA zeolites in selective catalytic reduction of NO with ammonia
}

Rafal Baran, Jean-Marc Krafft, Thomas Onfroy, Teresa Grzybek, Stanislaw

Dzwigaj

\section{To cite this version:}

Rafal Baran, Jean-Marc Krafft, Thomas Onfroy, Teresa Grzybek, Stanislaw Dzwigaj. Influence of the nature and environment of cobalt on the catalytic activity of Co-BEA zeolites in selective catalytic reduction of NO with ammonia. Microporous and Mesoporous Materials, 2016, 225, pp.515-523. 10.1016/j.micromeso.2015.12.061 . hal-01275301

\section{HAL Id: hal-01275301 \\ https://hal.science/hal-01275301}

Submitted on 9 Mar 2016

HAL is a multi-disciplinary open access archive for the deposit and dissemination of scientific research documents, whether they are published or not. The documents may come from teaching and research institutions in France or abroad, or from public or private research centers.
L'archive ouverte pluridisciplinaire HAL, est destinée au dépôt et à la diffusion de documents scientifiques de niveau recherche, publiés ou non, émanant des établissements d'enseignement et de recherche français ou étrangers, des laboratoires publics ou privés. 
Influence of the nature and environment of cobalt on the catalytic activity of Co-BEA zeolites in selective catalytic reduction of NO with ammonia

\author{
Rafal Baran ${ }^{1,2,3}$, Jean-Marc Krafft ${ }^{2,3}$, Thomas Onfroy ${ }^{2,3}$, \\ Teresa Grzybek ${ }^{1}$, Stanislaw Dzwigaj ${ }^{2,3, *}$ \\ ${ }^{1}$ Faculty of Energy and Fuels, AGH University of Science and Technology, Al. A. \\ Mickiewicza 30, 30-059 Krakow, Poland \\ ${ }^{2}$ Sorbonne Universités, UPMC Univ Paris 06, UMR 7197, Laboratoire de Réactivité de \\ Surface, F-75005, Paris, France \\ ${ }^{3}$ CNRS, UMR 7197, Laboratoire de Réactivité de Surface, F-75005, Paris, France
}

Figures: 10

Tables : 5

Keywords: Cobalt, BEA, postsynthesis, $\mathrm{SCR}$ of $\mathrm{NO}, \mathrm{NH}_{3}$

*Corresponding author:

Dzwigaj Stanislaw, E-mail : stanislaw.dzwigaj@upmc.fr, tel : 33144272113 


\begin{abstract}
The influence of cobalt environment on the catalytic properties of $\mathrm{Co}_{\mathrm{x}} \mathrm{SiBEA}$ zeolite in selective catalytic reduction of NO with ammonia was studied. Catalysts were prepared by a two-step postsynthesis method which consists, in the first step, of dealumination of parent BEA zeolite to obtain aluminum-free SiBEA support and then, in the second step, of contacting the obtained material with an aqueous solution of cobalt nitrate. DR UV-Vis and XPS results showed that cobalt was successfully incorporated into zeolite beta framework as isolated mononuclear $\mathrm{Co}(\mathrm{II})$. The presence of only isolated framework mononuclear $\mathrm{Co}(\mathrm{II})$ was evidenced in $\mathrm{Co}_{\mathrm{x}} \mathrm{SiBEA}$ with cobalt content lower than 2 wt $\%$ and both isolated framework mononuclear $\mathrm{Co}(\mathrm{II})$ and extra-framework octahedral $\mathrm{Co}(\mathrm{II})$ for $\mathrm{Co}_{3.0} \mathrm{SiBEA}$ catalyst. FTIR investigation of pyridine adsorption revealed that the incorporation of cobalt into zeolite framework led to a creation of new Lewis acidic sites which are responsible for high activity in SCR of NO with ammonia. The catalytic activity of $\mathrm{Co}_{\mathrm{x}} \mathrm{SiBEA}$ in selective catalytic reduction of NO with ammonia as reducing agent strongly depends on the nature and environment of cobalt in BEA structure. The single-site $\mathrm{Co}_{2.0} \mathrm{SiBEA}$ zeolite catalyst was the most active among tested, with maximum NO conversion about $80 \%$ at $673 \mathrm{~K}$. In contrast, $\mathrm{Co}_{3.0} \mathrm{SiBEA}$ catalyst containing a mixture of framework and extra-framework $\mathrm{Co}$ (II) had lower activity in SCR of $\mathrm{NO}$ process than $\mathrm{Co}_{2.0} \mathrm{SiBEA}$ at higher temperature due to a competitive reaction of ammonia oxidation to NO.
\end{abstract}




\section{Introduction}

Despite of numerous publications and much scientific research on selective catalytic reduction of $\mathrm{NO}_{\mathrm{x}}$ with ammonia [1-7] or hydrocarbons [8-11] as reducing agents, there is still a lot of questions about the reaction mechanism, as well as the formation of by-products as a result of competitive reactions of ammonia and hydrocarbons oxidation.

Moreover, improvements in currently used SCR technology are required. Another important factor from the point of view of industrial application in power plants and automotive engines is longtime catalyst stability and durability.

To obtain a very efficient catalyst for the removal of nitrogen oxides, excellent dispersion of active species is needed which will allow to hinder side reactions $[12,13]$. To achieve this, new methods of catalyst preparation should be developed because conventional ones result in the formation of different metal species. In the case of cobalt-containing zeolites isolated framework cobalt species, cobalt ions in ion-exchange positions, cobalt oxide clusters and crystallites and $\mathrm{Co}_{3} \mathrm{O}_{4}$ were found, depending on the conditions of preparation procedures $[12,14,15]$.

Recent works on the application of cobalt-containing materials for selective catalytic reduction of $\mathrm{NO}_{\mathrm{x}}$ with ammonia [16-19] or methane [20,21] gave promising results and established cobalt as an attractive active material for the removal of $\mathrm{NO}_{\mathrm{x}}$ from exhaust gases, but further investigation of cobalt speciation and optimal loading should be carried out.

In our work we obtained single-site cobalt zeolite catalyst due to the application of twostep postsynthesis method which consists of the creation of a vacant T-atom sites with associated silanol groups by dealumination of parent beta zeolite by treatment with nitric acid, and the following incorporation of cobalt in the framework of resulting SiBEA zeolite by its reaction with silanol groups [22]. With the combined use of various spectroscopy techniques, we have proved the formation of isolated framework mononuclear $\mathrm{Co}(\mathrm{II})$. 
The subject of this research was to study the influence of the nature and environment of cobalt present in Co-BEA zeolites on the selective catalytic reduction of $\mathrm{NO}$ with $\mathrm{NH}_{3}$.

\section{Experimental Section}

\subsection{Materials}

The two type of zeolite BEA samples were prepared. First series of $\mathrm{Co}_{\mathrm{x}} \mathrm{SiBEA}$ catalysts was prepared by two-step postsynthesis procedure. In the first step, $2 \mathrm{~g}$ of parent TEABEA zeolite was treated with $0.2 \mathrm{~L}$ of nitric acid aqueous solution $\left(13 \mathrm{~mol} \mathrm{~L}^{-1}\right)$ at $353 \mathrm{~K}$ for 4 hours in order to remove aluminum from zeolite framework. The obtained Al free SiBEA solid was washed several times with distilled water and dried overnight at $363 \mathrm{~K}$.

In the second step, $2 \mathrm{~g}$ of SiBEA zeolite was contacted with $0.2 \mathrm{~L}$ of cobalt nitrate solution with an appropriate concentration and kept for 24 hours under vigorous stirring. After this time the suspension was transferred into an evaporator and dried for two hours under vacuum pump. In this way, a set of zeolites was prepared and labeled: $\mathrm{Co}_{1.0} \mathrm{SiBEA}$, $\mathrm{Co}_{2.0} \mathrm{SiBEA}$ and $\mathrm{Co}_{3.0} \mathrm{SiBEA}$, where the number following the element symbol stands for the weight percentage of introduced cobalt.

HAlBEA zeolite was prepared by conventional ion exchange of AlBEA with 0.1 mol

$\mathrm{L}^{-1} \mathrm{dm}^{-3} \mathrm{NH}_{4} \mathrm{NO}_{3}$ solution following calcination of TEABEA for $15 \mathrm{~h}$ at $823 \mathrm{~K}$ as described earlier [23].

$\mathrm{Co}_{2.0} \mathrm{HAlBEA}$ were obtained by conventional wet impregnation of $2 \mathrm{~g}$ of HAlBEA with appropriate concentration of aqueous $\mathrm{Co}\left(\mathrm{NO}_{3}\right)_{2}$ solution [24]. This sample was prepared as reference for $\mathrm{Co}_{\mathrm{x}} \mathrm{SiBEA}$ zeolites.

\subsection{Apparatus and Procedures}


X-ray Fluorescence chemical analysis was performed at room temperature on SPECTRO X-LabPro apparatus.

XRD analysis was carried out on a PANalitical Empyrean diffractometer using the $\mathrm{CuK}_{\alpha}$ radiation $(\lambda=154.05 \mathrm{pm})$. All experiments were performed at room temperature. XRD relative crystallinity of the samples was calculated using the main diffraction reflex area form XRD patterns considering the TEABEA zeolite as $100 \%$ crystalline.

Low temperature nitrogen sorption experiments were carried out on a Micromeretics ASAP 2010 apparatus. All samples were outgassed, first at room temperature, then at $623 \mathrm{~K}$ to a pressure lower than $0.2 \mathrm{~Pa}$. The specific surface areas were determined using BET method. The microporous pore volume was determined from the amount of $\mathrm{N}_{2}$ adsorbed up to $\mathrm{P} / \mathrm{P}_{0}=0.2$

FTIR spectra in transmission mode were registered on PerkinElmer Frontier spectrometer. The mixture of $\mathrm{KBr}$ and zeolite sample (200:1) was carefully ground and pressed into a wafer under pressure of 2 tons $\mathrm{cm}^{-2}$. The framework vibrational spectra were recorded between 400 and $4000 \mathrm{~cm}^{-1}$ with a resolution of $4 \mathrm{~cm}^{-1}$.

DR UV-vis experiments were carried out at ambient atmosphere on a Cary 5000 Varian spectrometer equipped with a double integrator with polytetrafluoroethylene as reference.

XPS measurements were carried out with Omicron (ESCA+) spectrometer, using an $\mathrm{Al} \mathrm{K} \alpha(\mathrm{h} v=1486.6 \mathrm{eV}) \mathrm{X}$-ray source equipped with a flood gun. The sample area used for analysis was $3 \mathrm{~mm}^{2}$. Zeolite samples were pressed into an indium foil. Binding energy (BE) of $\mathrm{Co}, \mathrm{Si}$ and $\mathrm{O}$ was calibrated to the $\mathrm{Si} 2 \mathrm{p}$ peak at $103.3 \mathrm{eV}$. Before analysis, the samples were degassed at room temperature to a pressure of $10^{-7} \mathrm{~Pa}$. A number of components were determined with a Voigt function (a 70/30 composition of Gaussian and Lorentzian functions). 
Infrared spectroscopy of $\mathrm{CO}$ adsorption/desorption experiments were performed on a Bruker Vertex 70 spectrometer. Before analysis, self supported samples were pressed at ca. 1 tons $\mathrm{cm}^{-2}$ into thin wafers of ca. $10 \mathrm{mg} \mathrm{cm}^{-2}$ and set inside the glass cell where they were pretreated at $723 \mathrm{~K}$ for $2 \mathrm{~h}$ in flowing $2.5 \% \mathrm{O}_{2} / \mathrm{Ar}$ and then degassed at $573 \mathrm{~K}\left(10^{-3} \mathrm{~Pa}\right)$ for $1 \mathrm{~h}$.

Finally, IR cell was cooled down to $100 \mathrm{~K}$ with liquid nitrogen, and $\mathrm{CO}$ was added in small portions up to an equilibrium pressure of $133 \mathrm{~Pa}$. Then the sample was evacuated up to $10^{-3} \mathrm{~Pa}$ at room temperature. The spectra were obtained after subtraction of the spectrum recorded before $\mathrm{CO}$ adsorption.

The quantity of Brønsted and Lewis acidic sites was determined by adsorption of pyridine followed by infrared spectroscopy, using the parameters calculated by Emeis [25]. The samples were prepared in the same way as for the CO sorption experiments. The wafers activation procedure was performed as described before [22]. Bruker Vector 22 spectrometer (resolution $2 \mathrm{~cm}^{-1}, 128$ scans) was used to record the spectra after desorption from 423 and $573 \mathrm{~K}$ for $1 \mathrm{~h}$. The final spectra were obtained after subtraction of the spectrum recorded before pyridine adsorption from the spectrum recorded after pyridine adsorption.

The activity tests of cobalt containing catalysts in selective catalytic reduction (SCR) of NO with ammonia were performed in a fixed bed reactor. Temperature was measured inside the reactor with a thermocouple and controlled with an electronic controller (LUMEL RE19). The composition of the reaction gas was: $1000 \mathrm{ppm} \mathrm{NO}, 1000 \mathrm{ppm} \mathrm{NH}_{3}, 3.5$ vol.\% $\mathrm{O}_{2}$ and $\mathrm{He}$ as balance. The gas mixture was provided with calibrated electronic mass flow controllers (BETA-ERG). The total gas flow was $0.1 \mathrm{~L} \mathrm{~min}^{-1}$ and catalyst mass was $0.2 \mathrm{~g}$. The concentrations of $\mathrm{NO}$ and $\mathrm{N}_{2} \mathrm{O}$ after reaction were analyzed by FTIR detectors (ABB $2020 \mathrm{AO}$ series). Prior to the reaction the catalyst bed was activated in $3.5 \% \mathrm{O}_{2} / \mathrm{He}$ flow $(0.1$ $\mathrm{L} \mathrm{min}^{-1}$ ) in the temperature range of $298-798 \mathrm{~K}$ with a linear heating rate of $2 \mathrm{~K} \mathrm{~min}^{-1}$ and then for $1 \mathrm{~h}$ at $798 \mathrm{~K}$. The standard test was carried out over $1 \mathrm{~h}$ at 573-773 $\mathrm{K}$ with increasing 
reaction temperature every $50 \mathrm{~K}$ interval. The $\mathrm{NO}$ conversion was calculated from the measured concentration of nitric oxide.

Catalytic tests of ammonia oxidation were carried out in exactly the same way but without the presence of NO in the substrates stream.

\section{Results and Discussion}

\subsection{Structural stability of Cox SiBEA zeolites as evidenced by XRD and low temperature $\mathrm{N}_{2}$ sorption}

Table 1 exhibits the chemical composition of all samples mentioned in this work. The $\mathrm{Si} / \mathrm{Al}$ ratio of the parent zeolites TEABEA was 17 and for dealuminated samples was higher than 1000. The final contribution of Co was very close to theoretical one, calculated before sample preparation.

The X-ray diffractograms of TEABEA, HAlBEA, $\mathrm{Co}_{2.0} \mathrm{HAlBEA}, \mathrm{SiBEA}$, $\mathrm{Co}_{2.0} \mathrm{SiBEA}$ and $\mathrm{Co}_{3.0} \mathrm{SiBEA}$ catalysts are shown in Figure 1. All of them correspond to the pattern of zeolite beta structure [26,27]. As we reported before [23,28] shifts of narrow diffraction reflection located around $22.5^{\circ}$ are generally taken as evidence of lattice contraction or expansion. In the Table 2 structural characteristic of BEA samples are collected. The position of the main diffraction peak increase from $22.326^{\circ}$ for TEABEA to $22.493{ }^{\circ}$ for HAlBEA, and to $22.662^{\circ}$ for SiBEA indicating some relaxation of beta matrix related to removal of aluminum species form the framework. Introduction of cobalt into SiBEA zeolite led to the opposite shift of the main diffraction reflection from $22.662^{\circ}$ for SiBEA to $22.536^{\circ}$ for $\mathrm{Co}_{2.0} \mathrm{SiBEA}$ and to $22.530^{\circ}$ for $\mathrm{Co}_{3.0} \mathrm{SiBEA}$ suggesting incorporation of cobalt into the framework of zeolite.

Diffractograms of the $\mathrm{Co}_{\mathrm{x}} \mathrm{SiBEA}$ recorded after SCR of NO with ammonia were almost identical of those before this reaction (result not shown), indicating that upon SCR 
process the structure of the studied catalysts was not affected. No oxide phases were detected for spent-C-Co $\mathrm{Co}_{2.0} \mathrm{SiBEA}$ and spent-C- $-\mathrm{Co}_{3.0} \mathrm{SiBEA}$, confirming that sintering of cobalt species did not take place during the reaction.

As shown in Table 3, the textural properties of studied samples are typical for zeolite beta [29,30] and did not significant change neither over calcination for 15 hours at $823 \mathrm{~K}$ nor after treatment with nitric acid. Also formation of additional mesoporosity was not observed. Furthermore, the introduction of cobalt into SiBEA did not involve change of pore volume and specific surface area of zeolite.

An additional evidence of cobalt incorporation into the zeolite framework is strong modification of IR band at $950 \mathrm{~cm}^{-1}$ assigned to the stretching vibration of Si-O belonging to the uncoupled $\mathrm{SiO}_{4}$ tetrahedra with a hydroxyl group, in line with earlier work on BEA zeolite [31-33].

As it is seen on Figure 2, FTIR spectra of parent TEABEA zeolite do not exhibit peak at around $950 \mathrm{~cm}^{-1}$ indicating absence of structural damages. Calcination of the parent zeolite led to the appearance of low intense bond at $950 \mathrm{~cm}^{-1}$ on HAlBEA spectrum and the treatment with nitric acid involve a considerable increase in the intensity of this band suggesting the formation of vacant T-atom sites, in agreement with earlier reports [31-33].

After the contacting of SiBEA with cobalt precursor (aqueous solution of $\mathrm{Co}\left(\mathrm{NO}_{3}\right)_{2}$ ) the significant decreasing of the intensity of FTIR band at $950 \mathrm{~cm}^{-1}$ was observed and new band at $955 \mathrm{~cm}^{-1}$ was appeared indicating reaction of Co precursor with silanol groups of vacant T-atom sites and incorporation of cobalt into zeolite framework.

\subsection{Nature of cobalt in Co $\mathrm{o}_{x}$ SiBEA zeolites as determined by DR UV-Vis and XPS}

The DR UV-vis spectrum of the calcined $\mathrm{Co}_{2.0} \mathrm{SiBEA}\left(\mathrm{C}-\mathrm{Co}_{2.0} \mathrm{SiBEA}\right)$ zeolites (Fig. 3) exhibits two characteristic bands at 600 and $670 \mathrm{~nm}$, ascribed to isolated framework 
mononuclear Co(II), in agreement with the earlier reposts [34,35]. The DR UV-Vis spectrum of $\mathrm{C}-\mathrm{Co}_{3.0} \mathrm{SiBEA}$ catalyst containing $3.0 \mathrm{wt} \%$ of cobalt, besides the bands at 600 and $670 \mathrm{~nm}$, contains an additional one at $510 \mathrm{~nm}$, related to $\mathrm{Co}(\mathrm{II})$ species of octahedral coordination, in agreement with the earlier work on CoAPO-5 [36] and CoMOR [37] materials. Thus, for C$\mathrm{Co}_{3.0} \mathrm{SiBEA}$ catalyst, apart from the isolated framework mononuclear $\mathrm{Co}(\mathrm{II})$, extra-framework octahedral Co(II) may also be present, influencing its properties in the catalytic reaction.

DR UV-Vis spectrum of $\mathrm{C}-\mathrm{Co}_{2.0} \mathrm{HAlBEA}$ displays additional bond at $765 \mathrm{~nm}$ in comparison to $\mathrm{C}-\mathrm{Co}_{3.0} \mathrm{SiBEA}$ sample. This signal may be ascribed to oxygen-to-metal charge transfers for $\mathrm{Co}(\mathrm{III})$, in line with earlier studies for cobalt containing materials [38-40]. So, the presence of two types of $\mathrm{Co}(\mathrm{II})$ species in $\mathrm{C}-\mathrm{Co}_{2.0} \mathrm{HAlBEA}$, first one as isolated mononuclear $\operatorname{Co}(\mathrm{II})$ and second one as polynuclear $\mathrm{Co}(\mathrm{II})$ in octahedral environment as well as Co(III) species is confirmed.

The XPS experiments were carried out in the BE ranges corresponding to O 1s, Si 2p, and Co $2 p$ to elucidate the types of surface cobalt species present in $\mathrm{Co}_{\mathrm{x}} \mathrm{SiBEA}$ catalysts.

The XPS chemical composition of studied samples is summarized in Table 4. The $\mathrm{Si} / \mathrm{Al}$ ration of $\mathrm{C}-\mathrm{Co}_{2.0} \mathrm{HAlBEA}$ is very similar to the one calculated from XRF experiments. The lower Co/Si ratio for all Co-containing samples may be due to very high dispersion of cobalt species in whole zeolite grains.

The XP spectrum of $\mathrm{C}-\mathrm{Co}_{1.0} \mathrm{SiBEA}$ zeolite was described recently in our work [22] and it reveals signals of $\mathrm{Co}_{2} 2 \mathrm{p}_{3 / 2}$ and $\mathrm{Co} 2 \mathrm{p}_{1 / 2}$ at 780.5 and $796.0 \mathrm{eV}$ respectively, corresponding to cobalt present in the framework of BEA zeolite as isolated mononuclear $\mathrm{Co}(\mathrm{II})$, in line with the earlier reports on cobalt-containing zeolites [41,42]. The satellite peaks at 785.5 and $800.9 \mathrm{eV}$ are the evidence of shake-up electrons typical for cobalt(II).

In comparison, XPS spectrum of C-Co ${ }_{3.0} \operatorname{SiBEA}(\mathbf{F i g} .4)$ contains pair of peaks in both Co $2 p_{3 / 2}$ and Co $2 p_{1 / 2}$ ranges, suggesting the presence of two types of cobalt surface species. 
Besides the peaks at 780.4 and $796.1 \mathrm{eV}$ related to isolated framework mononuclear Co(II), additional ones at 781.7 and $797.7 \mathrm{eV}$ appeared, which might be linked to octahedral Co(II) in extra-framework positions in agreement with the study on cobalt modified LTL zeolite [15].

XPS spectrum of C-Co ${ }_{2.0} \mathrm{HAlBEA}$ zeolite reveals three values of $\mathrm{BE}$ of $\mathrm{Co} 2 \mathrm{p}_{3 / 2}$ and of Co $2 \mathrm{p}_{1 / 2}$ at $779.8,781.3,784.2 \mathrm{eV}$ and $795.9,797.5,800.3 \mathrm{eV}$, respectively. The values of Co $2 \mathrm{p}_{3 / 2}$ at $781.3 \mathrm{eV}$ and of $\mathrm{Co} 2 \mathrm{p}_{1 / 2}$ at $797.5 \mathrm{eV}$ may be assigned to very well dispersed extraframework mononuclear Co(II), in line with earlier observations on Co-ZSM5 and Co-beta zeolites $[35,43]$

However, the second values of BE of Co $2 p_{3 / 2}$ and Co $2 p_{1 / 2}$ peaks at 784.2 and 800.3 $\mathrm{eV}$, respectively, may be ascribed to polynuclear Co(II) $[13,41]$. Furthermore, the presence of additional peaks at 779.8 and $795.9 \mathrm{eV}$ suggests the presence of $\mathrm{Co}(\mathrm{III})$. It indicates that some amount of $\mathrm{Co}(\mathrm{II})$ introduced into HAlBEA was oxidized to $\mathrm{Co}(\mathrm{III})$ over thermal treatment at $773 \mathrm{~K}$ in air.

\subsection{The nature and strength of acidic centers as determined by FTIR of adsorbed pyridine and $\mathrm{CO}$}

Figure 5 displays the FTIR spectra of HAlBEA, $\mathrm{Co}_{2.0} \mathrm{HAlBEA}, \mathrm{SiBEA}, \mathrm{Co}_{2.0} \mathrm{SiBEA}$ and $\mathrm{Co}_{3.0} \mathrm{SiBEA}$ after adsorption of pyridine at room temperature and the following desorption at $423 \mathrm{~K}$ for 1 hour.

The acidic properties of HAlBEA and $\mathrm{Co}_{2.0} \mathrm{HAlBEA}$ were precisely describe in our earlier work [24]. HAlBEA contains large amount of strong Bronsted and Lewis acidic sites related to presence of $\mathrm{Si}-\mathrm{O}(\mathrm{H})-\mathrm{Al}$ groups and unsaturated $\mathrm{Al}(\mathrm{III})$ centers, respectively. Introduction of Co ions into HAlBEA leads to formation in $\mathrm{Co}_{2.0} \mathrm{HAlBEA}$ additional amount 
of Lewis acidic centers related to Co(II) and/or Co(III) species confirmed by appearance of intense bands at 1449 and $1611 \mathrm{~cm}^{-1}$.

For SiBEA a very low amount of Brønsted and Lewis acidic centers was proven (Table 5) by the appearance of low bands at 1546 and $1638 \mathrm{~cm}^{-1}$ typical for pyridine cations, and at $1455 \mathrm{~cm}^{-1}$, attributed to coordinatively bonded pyridine [28].

The introduction of cobalt into SiBEA led to the formation of high amount of Lewis acidic centers with a moderate strength, confirmed by the presence of high intense band at $1450 \mathrm{~cm}^{-1}$, in line with a similar observation for NiSiBEA zeolite [44]. However, for $\mathrm{Co}_{2.0} \mathrm{SiBEA}$, the amount of acidic centers is higher than for $\mathrm{Co}_{3.0} \mathrm{SiBEA}$ which may suggest that only Co incorporated into zeolite framework as isolated framework mononuclear Co(II) resulted in the creation of Lewis acidic centers, whereas the introduction of higher amount of cobalt led to the formation of extra-framework Co oligomers without further creation of Lewis acidic centers (Table 5). A lower amount of Lewis acidic centers determined by pyridine adsorption for $\mathrm{Co}_{3.0} \mathrm{SiBEA}$ than for $\mathrm{Co}_{2.0} \mathrm{SiBEA}$ may also be the result of blocking the access to the cobalt framework centers by Co oligomers located in the extra-framework positions of BEA zeolite. Table 5 additionally shows changes in the concentration of acidic centers after recording the spectra at the different temperatures. For $\mathrm{Co}_{2.0} \mathrm{SIBEA}$ and $\mathrm{Co}_{3.0} \mathrm{SiBEA}$ zeolites, after increasing temperature from 423 to $573 \mathrm{~K}$, a decrease in Lewis acidic centers concentration is about $38 \%$ and $42 \%$, respectively, suggesting a moderate acidic strength of isolate framework mononuclear $\mathrm{Co}(\mathrm{II})$.

In order to characterize the nature of cobalt species and the strength of acidic centers in CoSiBEA, CO adsorption following FTIR experiments was carried out.

FTIR spectra of carbon monoxide adsorbed on activated $\mathrm{Co}_{2.0} \mathrm{SiBEA}$ zeolite (Fig. 6A) exhibit five different bands in the carbonyl region at 2133, 2160, 2174, 2185 and $2215 \mathrm{~cm}^{-1}$. The bands at 2160 and $2174 \mathrm{~cm}^{-1}$ are assigned to $\mathrm{CO}$ interacting with SiO-H group and 
bridged $\mathrm{Si}-\mathrm{O}(\mathrm{H})-\mathrm{Al}$, respectively, in line with earlier reports $[23,45]$. The latter appeared due to a small amount of framework aluminum remaining in SiBEA after treatment of TEABEA with nitric acid in the first step of the preparation procedure. According to the investigation of Hadjiivanov et al. on Co-ZMS-5 [46,47], and cobalt containing BEA zeolite [48] as studied by Mihaylova et al., the bands at 2185 and $2215 \mathrm{~cm}^{-1}$ are assigned to two types of monocarbonyl species formed after $\mathrm{CO}$ adsorption on the framework $\mathrm{Co}$ (II) species. Comparing the intensities of the two mentioned bands, the former cobalt species had much higher concentration. The remaining band at $2133 \mathrm{~cm}^{-1}$ is correlated with physically adsorbed CO molecules [7].

To describe the strength of hydroxyl groups present in $\mathrm{Co}_{2.0} \mathrm{SiBEA}$, the analysis of FTIR spectra in $\mathrm{OH}$ groups vibration range after $\mathrm{CO}$ sorption were performed.

The difference spectra (Fig. 6B) reveal four positive bands at 3653, 3435, 3345 and $3261 \mathrm{~cm}^{-1}$, as well as one negative band at $3738 \mathrm{~cm}^{-1}$. The FTIR band at $3738 \mathrm{~cm}^{-1}$ is attributed to internal silanol groups in line with earlier works [49]. The positive bands at 3653,3435 and $3345 \mathrm{~cm}^{-1}$ appeared as the shift of bands related to internal $\mathrm{SiO}-\mathrm{H}, \mathrm{AlO}-\mathrm{H}$ and acidic hydroxyl groups present in BEA zeolite, respectively, in agreement with earlier report [23].

A small shift from $3738 \mathrm{~cm}^{-1}$ to $3653 \mathrm{~cm}^{-1}$ (blue shift, $85 \mathrm{~cm}^{-1}$ ) for the isolated silanol groups indicates that they posses very weak acidic character. The band at 3435 and $3345 \mathrm{~cm}^{-1}$ resulted from a shift of bands primarily located at 3660 and $3608 \mathrm{~cm}^{-1}$, respectively. The considerable shifts of AlO-H $\left(225 \mathrm{~cm}^{-1}\right)$ and $\mathrm{Si}-\mathrm{O}(\mathrm{H})-\mathrm{Al}\left(263 \mathrm{~cm}^{-1}\right)$ indicate a very strong acidic character of both Lewis and Brønsted centers. However, because of low intensity of these bands, a very low concentration of acidic centers related to aluminum sites is confirmed in $\mathrm{Co}_{2.0} \mathrm{SiBEA}$ catalyst. 
Fig. 7A shows the changes in the carbonyl region after gradual evacuation. The first bands present at 2140 and $2133 \mathrm{~cm}^{-1}$, which disappeared upon outgassing, correspond to very weakly coordinated CO. Then $2160 \mathrm{~cm}^{-1}$ band was removed, indicating weak interactions between silanol groups and carbon monoxide. Further evacuation led to a partial disappearance of the bands at 2174, 2215 and $2185 \mathrm{~cm}^{-1}$. These results show that the most stable interactions occurred between $\mathrm{CO}$ and acidic hydroxyls, as well as cobalt(II), confirming strong acidic character of both species.

Similar conclusion may be drawn after the analysis of hydroxyl region of the spectra recorded on gradually evacuated $\mathrm{Co}_{2.0}$ SIBEA sample (Fig. 7B). The first band which disappeared is that at $3660 \mathrm{~cm}^{-1}$, confirming very low acidic strength of SiO-H groups. The bands at 3379 and $3257 \mathrm{~cm}^{-1}$ related to aluminum species forming strong Lewis and strong Brønsted acidic centers, remained the longest during outgassing of $\mathrm{Co}_{2.0} \mathrm{SiBEA}$ sample.

\subsection{Catalytic activity of Co $\mathrm{C}$ SiBEA zeolites}

The $\mathrm{Co}_{1.0} \mathrm{SiBEA}, \mathrm{Co}_{2.0} \mathrm{SiBEA}, \mathrm{Co}_{3.0} \mathrm{SiBEA}$ and $\mathrm{Co}_{2.0} \mathrm{HAlBEA}$ zeolites were tested in selective catalytic reduction of NO with ammonia. SCR reaction on cobalt containing catalyst goes according to following scheme:

$$
4 \mathrm{NH}_{3}+4 \mathrm{NO}+\mathrm{O}_{2}=4 \mathrm{~N}_{2}+6 \mathrm{H}_{2} \mathrm{O}
$$

However, often secondary reaction

$$
4 \mathrm{NH}_{3}+4 \mathrm{NO}+3 \mathrm{O}_{2}=4 \mathrm{~N}_{2} \mathrm{O}+6 \mathrm{H}_{2} \mathrm{O}
$$

or competitive ammonia oxidation reactions

$$
\begin{aligned}
2 \mathrm{NH}_{3}+2 \mathrm{O}_{2} & =\mathrm{N}_{2} \mathrm{O}+3 \mathrm{H}_{2} \mathrm{O} \\
4 \mathrm{NH}_{3}+5 \mathrm{O}_{2} & =4 \mathrm{NO}+6 \mathrm{H}_{2} \mathrm{O} \\
4 \mathrm{NH}_{3}+3 \mathrm{O}_{2} & =2 \mathrm{~N}_{2}+6 \mathrm{H}_{2} \mathrm{O}
\end{aligned}
$$


occur due to non-selectivity of the applied Co-catalysts, resulting in the formation of different kinds of $\mathrm{Co}(\mathrm{II})$ and $\mathrm{Co}(\mathrm{III})$ species, thus leading to low efficiency, especially at high temperature range $[12,16,19]$.

NO conversion for $\mathrm{Co}_{\mathrm{x}} \mathrm{SiBEA}$ is presented in Figure 8. SiBEA support showed very low activity in the whole temperature range. Maximum NO conversion was achieved at 623 and $673 \mathrm{~K}$ and did not exceed $15 \%$. The application of catalysts containing cobalt species resulted in the increase in NO conversion. Depending on the cobalt content, different activity was achieved at a given temperature. $\mathrm{Co}_{1.0} \mathrm{SiBEA}$ and $\mathrm{Co}_{2.0} \mathrm{SiBEA}$ catalysts present a typical volcano-like activity in selective catalytic reduction of NO with ammonia. The highest activity for these catalysts was achieved at $623-723 \mathrm{~K}$ with the maximum NO conversion of $79 \%$ at $673 \mathrm{~K}$ for $\mathrm{Co}_{2.0} \mathrm{SiBEA}$ catalyst. Such high activity is related to the presence of isolated framework mononuclear $\mathrm{Co}(\mathrm{II})$ whose presence was confirmed by XPS, DR UV-Vis and FTIR results.

In contrast, $\mathrm{Co}_{3.0} \mathrm{SiBEA}$ catalyst behaved differently. For this catalyst, $\mathrm{NO}$ conversion quickly decreased with the increasing temperature from $50 \%$ at $573 \mathrm{~K}$ to $4 \%$ at $773 \mathrm{~K}$. This behavior may be related to catalyst deactivation or competitive ammonia oxidation reactions. The similar behavior with the increasing of Co content was observed earlier for Co-ZSM-5 zeolites and cobalt containing mesoporous silica [12].

For $\mathrm{Co}_{2.0} \mathrm{HAlBEA}$ catalyst, $\mathrm{NO}$ conversion increased with temperature and reached maximum of $65 \%$ at $773 \mathrm{~K}$. Much lower activity in the $573-723 \mathrm{~K}$ temperature region for this sample compare to $\mathrm{Co}_{2.0} \mathrm{SiBEA}$ indicates that extra-framework cobalt species present in $\mathrm{Co}_{2.0} \mathrm{HAlBEA}$ are less active sites in SCR of $\mathrm{NO}$ with ammonia than isolated framework mononuclear cobalt(II) present in $\mathrm{Co}_{2.0} \mathrm{SiBEA}$.

As shown in Figure 9 for all studied catalysts the formation of $\mathrm{N}_{2} \mathrm{O}$ was observed, however at very low level in whole temperature range. The highest nitrous oxide 
concentration $-42 \mathrm{ppm}$ - was detected for $\mathrm{Co}_{3.0} \mathrm{SiBEA}$ catalyst at $773 \mathrm{~K}$. This by-product may come from both $\mathrm{NH}_{3}$ oxidation (reaction (4)) and SCR process itself.

In order to check the occurrence of side ammonia oxidation reaction, the catalytic tests were carried out without NO and the results are presented in Figure 10. All catalysts showed poor ability for oxidation of $\mathrm{NH}_{3}$ into $\mathrm{N}_{2} \mathrm{O}$ while for some of them significant amount of $\mathrm{NO}$ was detected. The increase in NO formation was observed with the increasing cobalt content. Very high amounts of $\mathrm{NO}$ were formed (> $225 \mathrm{ppm}$ at $773 \mathrm{~K}$ ) when $\mathrm{Co}_{3.0} \mathrm{SiBEA}$ catalyst was applied. With the increase in reaction temperature, the increase of NO concentration in the products was registered. These observations confirm that extra-framework cobalt(II) species present in $\mathrm{Co}_{3.0} \mathrm{SiBEA}$ zeolite are more active in the oxidation of ammonia to nitrogen(II) oxide than in the reduction of $\mathrm{NO}$ to $\mathrm{N}_{2}$ and $\mathrm{H}_{2} \mathrm{O}$ in selective catalytic redaction of NO with ammonia. Thus, the sharp decrease of NO conversion in selective catalytic reduction of NO at high temperature was due to the formation of $\mathrm{NO}$ as a result of ammonia oxidation and not catalyst deactivation. Similar conclusion was drawn by Chmielarz et al. in their work on cobalt containing hydrotalcite [19]. On the other hand, the catalyst containing predominantly isolated framework mononuclear cobalt(II) species showed high conversion of NO into $\mathrm{N}_{2}$ with the absence of undesired products.

From the results presented in this work it may be concluded that the application in SCR of NO with ammonia of CoSiBEA zeolite catalysts with predominantly isolated mononuclear $\mathrm{Co}(\mathrm{II})$ incorporated into zeolite framework led to several advantages, such as: (i) a very high efficiency of these catalysts at a wide temperature range (573 - 773), (ii) a higher activity of CoSiBEA catalysts with low Co content than other Co-containing catalyst with much higher Co content $[12,16,19]$, and (iii) the absence of hazardous side-product $\left(\mathrm{N}_{2} \mathrm{O}\right)$. 


\section{Conclusions}

XPS, DR UV-Vis and FTIR studies revealed that in $\mathrm{Co}_{\mathrm{x}} \mathrm{SiBEA}$ catalysts with 2 or less Co wt \%, prepared by the two-step postsynthesis method, cobalt occurs as isolated mononuclear $\mathrm{Co}(\mathrm{II})$ incorporated into zeolite framework. On the other hand, $\mathrm{Co}_{3.0} \mathrm{SiBEA}$ catalyst contains a mixture of framework and extra-framework Co(II) species.

Pyridine sorption followed by FTIR experiments allowed to establish that the incorporation of cobalt into zeolite framework resulted in the formation of new Lewis acidic sites with moderate strength.

The application of $\mathrm{Co}_{\mathrm{x}} \mathrm{SiBEA}$ zeolites with predominantly isolated mononuclear $\mathrm{Co}$ (II) as catalyst of selective catalytic reduction of NO with ammonia led to high NO conversion at the wide temperature range, with the maximum of $79 \%$ at $673 \mathrm{~K}$ for $\mathrm{Co}_{2.0} \mathrm{SiBEA}$.

$\mathrm{Co}_{3.0} \mathrm{SiBEA}$ containing the mixture of framework and extra-framework cobalt species was inactive in $\mathrm{NH}_{3}$-SCR process at high temperature range because of the preferential ammonia oxidation to NO.

For all catalysts negligible formation of $\mathrm{N}_{2} \mathrm{O}$ was found.

\section{Acknowledgment}

This project was funded by the National Science Center "PRELUDIUM" UMO2012/07/N/ST5/00171 (R.B., S.D.). 


\section{References}

[1] C. He, Y. Wang, Y. Cheng, C.K. Lambert, R.T. Yang,

Appl. Catal. A Gen. 368 (2009)121.

[2] A. Sultana, M. Sasaki, H. Hamada, Catal. Today 185 (2012) 284.

[3] S.S.R. Putluru, A. Riisager, R. Fehrmann, Appl. Catal. B Environ. 97 (2010) 333.

[4] I. Lezcano-Gonzalez, U. Deka, H.E. van der Bij, P. Paalanen, B. Arstad, B.M.

Weckhuysen, a. M. Beale, Appl. Catal. B Environ. 154-155 (2014) 339.

[5] M. Motak, Catal. Today 137 (2008) 247.

[6] J. Klinik, B. Samojeden, T. Grzybek, W. Suprun, H. Papp, R. Gläser,

Catal. Today 176 (2011) 303.

[7] R. Baran, T. Onfroy, T. Grzybek, S. Dzwigaj,

Appl. Catal. B 136-137 (2013) 186.

[8] S. Sitshebo, A. Tsolakis, K. Theinnoi, Int. J. Hydrogen Energy 34 (2009) 7842.

[9] J. Janas, J. Gurgul, R.P. Socha, S. Dzwigaj, Appl. Catal. B Environ. 91 (2009) 217.

[10] C. Thomas, Appl. Catal. B Environ. 162 (2015) 454.

[11] L. Righini, L. Kubiak, S. Morandi, L. Castoldi, L. Lietti, P. Forzatti,

ACS Catal. 4 (2014) 3261. 
[12] F. Bin, C. Song, G. Lv, J. Song, X. Cao, H. Pang, K. Wang,

J. Phys. Chem. C 116 (2012) 26262.

[13] J. Janas, T. Machej, J. Gurgul, R.P. Socha, M. Che, S. Dzwigaj,

Appl. Catal. B Environ. 75 (2007) 239.

[14] S.-J. Jong, S. Cheng, Appl. Catal. A Gen. 126 (1995) 51.

[15] C. Montes de C, A. Luz Villa de P, M.. Ramírez-Corredores,

Appl. Catal. A 197 (2000) 151.

[16] R. Moreno-Tost, J. Santamaría-González, P. Maireles-Torres, E. Rodríguez-Castellón,

A. Jiménez-López, Appl. Catal. B Environ. 38 (2002) 51.

[17] R. Moreno-Tost, J. Santamaría-González, E. Rodríguez-Castellón, A. Jiménez-López,

Appl. Catal. B Environ. 52 (2004) 241.

[18] M. Brandhorst, J. Zajac, D.J. Jones, J. Rozière, M. Womes, a. Jimenez-López, E.

Rodríguez-Castellón, Appl. Catal. B Environ. 55 (2005) 267.

[19] L. Chmielarz, P. Kuśtrowski, A. Rafalska-Łasocha, D. Majda, R. Dziembaj,

Appl. Catal. B Environ. 35 (2002) 195.

[20] F. Lónyi, H.E. Solt, Z. Pászti, J. Valyon, Appl. Catal. B Environ. 150-151 (2014) 218.

[21] F. Lónyi, H.E. Solt, J. Valyon, A. Boix, L.B. Gutierrez, 
J. Mol. Catal. A Chem. 345 (2011) 75.

[22] R. Baran, T. Onfroy, S. Casale, S. Dzwigaj, J. Phys. Chem. C 118 (2014) 20445.

[23] R. Baran, Y. Millot, T. Onfroy, J.M. Krafft, S. Dzwigaj,

Microporous Mesoporous Mater. 163 (2012) 122.

[24] A. Śrębowata, R. Baran, I.I. Kamińska, T. Onfroy, J.-M. Krafft, S. Dzwigaj,

Catal.Today 251 (2015) 73.

[25] C.A. Emeis, J. Catal. 141 (1993) 347.

[26] M. Trombetta, G. Busca, L. Storaro, M. Lenarda, M. Casagrande, A. Zambon,

Phys.Chem. Chem. Phys. 2 (2000) 3529.

[27] Y. Gong, T. Dou, S. Kang, Q. Li, Y. Hu, Fuel Process. Technol. 90 (2009) 122.

[28] R. Baran, Y. Millot, T. Onfroy, F. Averseng, J.-M. Krafft, S. Dzwigaj,

Microporous Mesoporous Mater. 161 (2012) 179.

[29] A. Petushkov, G. Merilis, S.C. Larsen, Microporous Mesoporous Mater. 143 (2011) 97.

[30] J.C. Groen, S. Abelló, L. a. Villaescusa, J. Pérez-Ramírez, Microporous Mesoporous

Mater. 114 (2008) 93.

[31] Q.-H. Xia, S.-C. Shen, J. Song, S. Kawi, K. Hidajat, J. Catal. 219 (2003) 74.

[32] C. Yang, Q. Xu, Zeolites 19 (1997) 404. 
[33] R. Dimitrova, G. Gunduz, L. Dimitrov, T. Tsoncheva, S. Yialmaz, E. a. Urquieta

Gonzalez, J. Mol. Catal. A Chem. 214 (2004) 265.

[34] G. Prieto, A. Martínez, P. Concepción, R. Moreno-Tost, J. Catal. 266 (2009) 129.

[35] C. Chupin, a. C. van Veen, M. Konduru, J. Després, C. Mirodatos,

J. Catal. 241 (2006) 103.

[36] P. Selvam, S. Mohapatra, J. Catal. 233 (2005) 276.

[37] M. Kato, T. Ikeda, T. Kodaira, S. Takahashi, Microporous Mesoporous Mater. 142

(2011) 444.

[38] L. Zhang, L. Dong, W. Yu, L. Liu, Y. Deng, B. Liu, H. Wan, F. Gao, K. Sun, L. Dong,

J. Colloid Interface Sci. 355 (2011) 464.

[39] J. Liu, Z. Zhao, J. Wang, C. Xu, A. Duan, G. Jiang, Q. Yang,

Appl. Catal. B Environ.84 (2008) 185.

[40] A. Boix, E.E. Miró, E.A. Lombardo, M.A. Banares, R. Mariscal, J.L.G. Fierro,

J. Catal.217 (2003) 186.

[41] L.P. Oleksenko, Theor. Exp. Chem. 40 (2004) 331.

[42] T.L. Barr, J. Vac. Sci. Technol. A Vacuum, Surfaces, Film. 9 (1991) 1793.

[43] H.-H. Chen, S.-C. Shen, X. Chen, S. Kawi, Appl. Catal. B Environ. 50 (2004) 37. 
[44] A. Śrebowata, R. Baran, D. Łomot, D. Lisovytskiy, T. Onfroy, S. Dzwigaj,

Appl. Catal. B Environ. 147 (2014) 208.

[45] K. Hadjiivanov, E. Ivanova, R. Kefirov, J. Janas, A. Plesniar, S. Dzwigaj, M. Che,

Microporous Mesoporous Mater. 131 (2010) 1.

[46] K. Hadjiivanov, B. Tsyntsarski, T. Venkov, M. Daturi, J. Saussey, J.-C. Lavalley,

Phys.Chem. Chem. Phys. 5 (2002) 243.

[47] K. Hadjiivanov, B. Tsyntsarski, T. Venkov, D. Klissurski, M. Daturi, J. Saussey, J.-C.

Lavalley, Phys. Chem. Chem. Phys. 5 (2003) 1695.

[48] A. Mihaylova, K. Hadjiivanov, S. Dzwigaj, M. Che,

J. Phys. Chem. B 110 (2006) 19530.

[49] E. Ivanova, K. Hadjiivanov, S. Dzwigaj, M. Che,

Microporous Mesoporous Mater. 89 (2006) 69. 
Table 1. Chemical composition of BEA samples.

\begin{tabular}{|c|c|c|c|c|c|}
\hline \multirow{2}{*}{ Sample } & \multicolumn{3}{|c|}{ Concentration (wt \%) } & \multicolumn{2}{c|}{ Ratio } \\
\cline { 2 - 6 } & $\mathrm{Co}$ & $\mathrm{Si}$ & $\mathrm{Al}$ & $\mathrm{Si} / \mathrm{Al}$ & $\mathrm{Co} / \mathrm{Si}$ \\
\hline $\mathrm{TEABEA}$ & - & 44.2 & 2.649 & 17 & - \\
\hline $\mathrm{HAlBEA}$ & - & 44.25 & 2.245 & 20 & - \\
\hline $\mathrm{Co}_{2.0} \mathrm{HAlBEA}$ & 2.21 & 42.9 & 2.143 & 20 & 0.052 \\
\hline $\mathrm{SiBEA}$ & - & 42.49 & 0.028 & $>1000$ & - \\
\hline $\mathrm{Co}_{1.0} \mathrm{SiBEA}$ & 1.12 & 45.54 & 0.037 & $>1000$ & 0.024 \\
\hline $\mathrm{Co}_{2.0} \mathrm{SiBEA}$ & 2.16 & 44.8 & 0.037 & $>1000$ & 0.048 \\
\hline $\mathrm{Co}_{3.0} \mathrm{SiBEA}$ & 3.63 & 42.91 & 0.024 & $>1000$ & 0.085 \\
\hline
\end{tabular}


Table 2. Structural properties of BEA samples.

\begin{tabular}{|c|c|c|c|}
\hline Sample & $2 \theta(\circ)$ & $\mathrm{d}_{302}(\AA)$ & $\begin{array}{c}\text { XRD relative } \\
\text { intensity }(\%)\end{array}$ \\
\hline TEABEA & 22.326 & 3.9788 & 100 \\
\hline HAlBEA & 22.493 & 3.9497 & 88 \\
\hline $\mathrm{Co}_{2.0} \mathrm{HAlBEA}$ & 22.447 & 3.9576 & 86 \\
\hline SiBEA & 22.662 & 3.9206 & 58 \\
\hline $\mathrm{Co}_{2.0} \mathrm{SiBEA}$ & 22.536 & 3.9421 & 64 \\
\hline spent-Co ${ }_{2.0} \mathrm{SiBEA}$ & 22.460 & 3.9553 & 59 \\
\hline $\mathrm{Co}_{3.0} \mathrm{SiBEA}$ & 22.530 & 3.9432 & 58 \\
\hline spent-Co ${ }_{3.0} \mathrm{SiBEA}$ & 22.531 & 3.9437 & \\
\hline
\end{tabular}


Table 3. Textural properties of HAlBEA, $\mathrm{Co}_{2.0} \mathrm{HAlBEA}$, SiBEA and $\mathrm{Co}_{1.0} \mathrm{SiBEA}$.

\begin{tabular}{|c|c|c|c|c|}
\hline Samples & $\begin{array}{c}\text { Specific surface } \\
\text { area } \\
\mathrm{S}_{\mathrm{BET}},\left(\mathrm{m}^{2} \mathrm{~g}^{-1}\right)\end{array}$ & $\begin{array}{c}\text { Micropores } \\
\text { volume } \\
\mathrm{V}_{\text {mic }},\left(\mathrm{mL} \mathrm{g}^{-1}\right)\end{array}$ & $\begin{array}{c}\text { Total pore } \\
\text { volume } \\
\mathrm{V}_{\text {tot }},\left(\mathrm{mL} \mathrm{g}^{-1}\right)\end{array}$ & $\begin{array}{c}\text { Average pores } \\
\text { diameter } \\
\mathrm{D},(\mathrm{nm})\end{array}$ \\
\hline HAlBEA & 641 & 0.26 & 0.38 & 2.67 \\
\hline $\mathrm{Co}_{2.0} \mathrm{HAlBEA}$ & 577 & 0.23 & 0.39 & 2.89 \\
\hline SiBEA & 612 & 0.25 & 0.37 & 2.64 \\
\hline $\mathrm{Co}_{1.0} \mathrm{SiBEA}$ & 613 & 0.25 & 0.38 & 2.76 \\
\hline
\end{tabular}


Table 4. XPS chemical analysis of C-Co ${ }_{1.0} \mathrm{SiBEA}, \mathrm{C}-\mathrm{Co}_{3.0} \mathrm{SiBEA}$ and $\mathrm{C}-\mathrm{Co}_{2.0} \mathrm{HAlBEA}$.

\begin{tabular}{|c|c|c|c|c|c|c|c|}
\hline \multirow{2}{*}{\begin{tabular}{c} 
Sample \\
\cline { 2 - 8 }
\end{tabular}} & \multicolumn{4}{|c|}{ Composition (at. \%) } & \multicolumn{2}{c|}{ Ratio } \\
\cline { 2 - 8 } & $\mathrm{Si} 2 \mathrm{p}$ & $\mathrm{O} 1 \mathrm{~s}$ & $\mathrm{C} 1 \mathrm{~s}$ & $\mathrm{Al} 2 \mathrm{p}$ & $\mathrm{Co} 2 \mathrm{p}$ & $\mathrm{Co} / \mathrm{Si}$ & $\mathrm{Si} / \mathrm{Al}$ \\
\hline $\mathrm{C}-\mathrm{Co}_{1.0} \mathrm{SiBEA}$ & 29.7 & 55.13 & 14.99 & $-*$ & 0.18 & 0.006 & - \\
\hline $\mathrm{C}-\mathrm{Co}_{3.0} \mathrm{SiBEA}$ & 29.26 & 55.89 & 14.43 & - & 0.42 & 0.014 & - \\
\hline${\mathrm{C}-\mathrm{Co}_{2.0} \mathrm{HAlBEA}}^{*}$ & 28.81 & 55.48 & 13.88 & 1.51 & 0.32 & 0.011 & 19.08 \\
\hline
\end{tabular}

* - aluminum was not detected 
Table 5. The amounts of Brønsted and Lewis acidic centers in SiBEA, $\mathrm{Co}_{2.0} \mathrm{SiBEA}$ and $\mathrm{Co}_{3.0} \mathrm{SiBEA}$.

\begin{tabular}{|c|c|c|c|c|c|c|}
\hline \multirow{2}{*}{$\begin{array}{c}\text { Type of acidic } \\
\text { centers }\end{array}$} & \multirow{2}{*}{ Temp.(K) } & \multicolumn{5}{|c|}{ Sample } \\
\cline { 3 - 7 } & HAlBEA & Co $_{2.0}$ HAlBEA & SiBEA & Co $_{2.0}$ SiBEA & Co $_{3.0}$ SiBEA \\
\hline $\begin{array}{c}\text { Brønsted acidic } \\
c^{c e n t e r s} \\
\left(\mu \mathrm{mol} \mathrm{g}^{-1}\right)\end{array}$ & 423 & 334 & 130 & 15 & 15 & 8 \\
\cline { 2 - 7 } & 573 & 239 & 58 & 8 & 0 & 0 \\
\hline $\begin{array}{c}\text { Lewis acidic } \\
\text { centers }_{\left(\mu \mathrm{mol}^{-1}\right)}\end{array}$ & 523 & 136 & 352 & 2 & 177 & 159 \\
\cline { 2 - 7 } & 573 & 137 & 268 & 1 & 111 & 91 \\
\hline
\end{tabular}




\section{Figure Captions}

Figure 1. XRD patterns recorded at room temperature of TEABEA, HAlBEA, $\mathrm{Co}_{2.0} \mathrm{HAlBEA}$, SiBEA, $\mathrm{Co}_{2.0} \mathrm{SiBEA}$ and $\mathrm{Co}_{3.0} \mathrm{SiBEA}$.

Figure 2. FTIR spectra recorded at ambient atmosphere of TEABEA, HAIBEA, SiBEA, and $\mathrm{C}-\mathrm{Co}_{2.0} \mathrm{SiBEA}$ in skeleton vibrations range.

Figure 3. DR UV-vis spectra recorded at ambient atmosphere of $\mathrm{C}-\mathrm{Co}_{2.0} \mathrm{SiBEA}$ and $\mathrm{C}$ $\mathrm{Co}_{3.0} \mathrm{SiBEA}$

Figure 4. XPS spectra recorded at room temperature of Co $2 \mathrm{p}$ core level of $\mathrm{C}-\mathrm{Co}_{1.0} \mathrm{SiBEA}, \mathrm{C}-$ $\mathrm{Co}_{3.0} \mathrm{SiBEA}$ and $\mathrm{C}-\mathrm{Co}_{2.0} \mathrm{HAlBEA}$.

Figure 5. FTIR spectra recorded at room temperature of $\mathrm{SiBEA}, \mathrm{Co}_{2.0} \mathrm{SiBEA}$ and $\mathrm{Co}_{3.0} \mathrm{SiBEA}$ after adsorption of pyridine (133 Pa) for $1 \mathrm{~h}$ at room temperature and desorption at $423 \mathrm{~K}$ for $1 \mathrm{~h}$.

Figure 6. FTIR difference spectra in carbonyl (A) and hydroxyl (B) stretching regions of $\mathrm{Co}_{2.0} \mathrm{SiBEA}$ after adsorption of a small dose (ca. $10 \mu \mathrm{mol} \mathrm{g}^{-1}$ (a-d) then $45 \mu \mathrm{mol} \mathrm{g}^{-1}$ (e-f) of $\mathrm{CO}$ at $100 \mathrm{~K}$.

Figure 7. FTIR spectra of $\mathrm{CO}$ (267 Pa equilibrium pressure) adsorbed at $100 \mathrm{~K}$ on $\mathrm{C}$ $\mathrm{Co}_{2.0} \mathrm{SiBEA}$ and evolution of the spectra in dynamic vacuum at $100 \mathrm{~K}(\mathrm{a}-\mathrm{g})$; carbonyl (A) and hydroxyl (B) stretching regions.

Figure 8. $\mathrm{NO}$ conversion in $\mathrm{SCR}$ of $\mathrm{NO}$ with $\mathrm{NH}_{3}$ on HAlBEA, $\mathrm{Co}_{2.0} \mathrm{HAlBEA}$, SiBEA, $\mathrm{Co}_{1.0} \mathrm{SiBEA}, \mathrm{Co}_{2.0} \mathrm{SiBEA}$ and $\mathrm{Co}_{3.0} \mathrm{SiBEA}$.

Figure 9. $\mathrm{N}_{2} \mathrm{O}$ formation in $\mathrm{SCR}$ of $\mathrm{NO}$ with $\mathrm{NH}_{3}$ on $\mathrm{SiBEA}, \mathrm{Co}_{1.0} \mathrm{SiBEA}, \mathrm{Co}_{2.0} \mathrm{SiBEA}$ $\mathrm{Co}_{3.0} \mathrm{SiBEA}$ and $\mathrm{Co}_{2.0} \mathrm{HAlBEA}$.

Figure $10 \mathrm{NO}$ and $\mathrm{N}_{2} \mathrm{O}$ formation in $\mathrm{NH}_{3}$ oxidation on $\mathrm{Co}_{2.0} \mathrm{SiBEA}$ and $\mathrm{Co}_{3.0} \mathrm{SiBEA}$. 


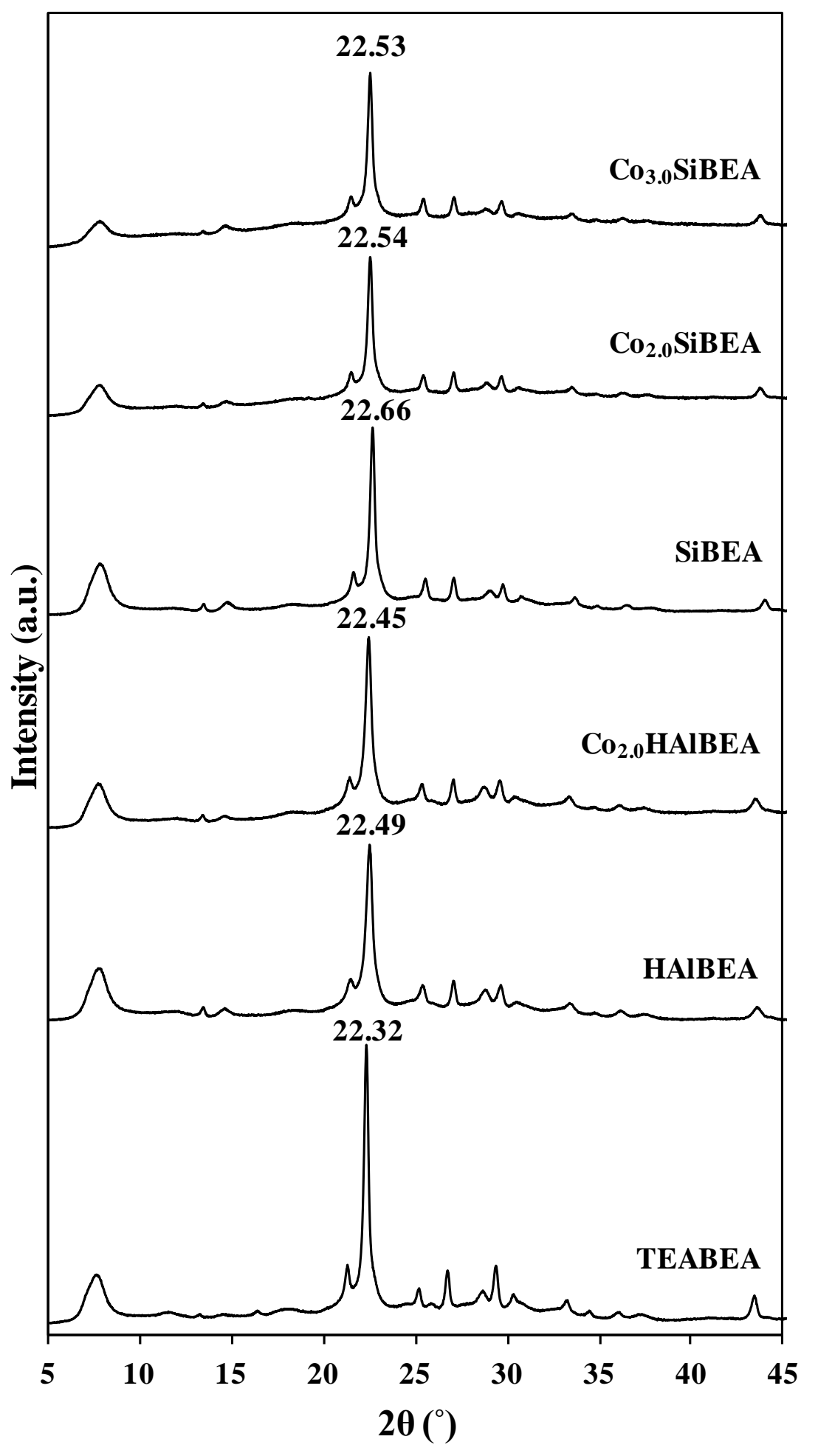

Figure 1 


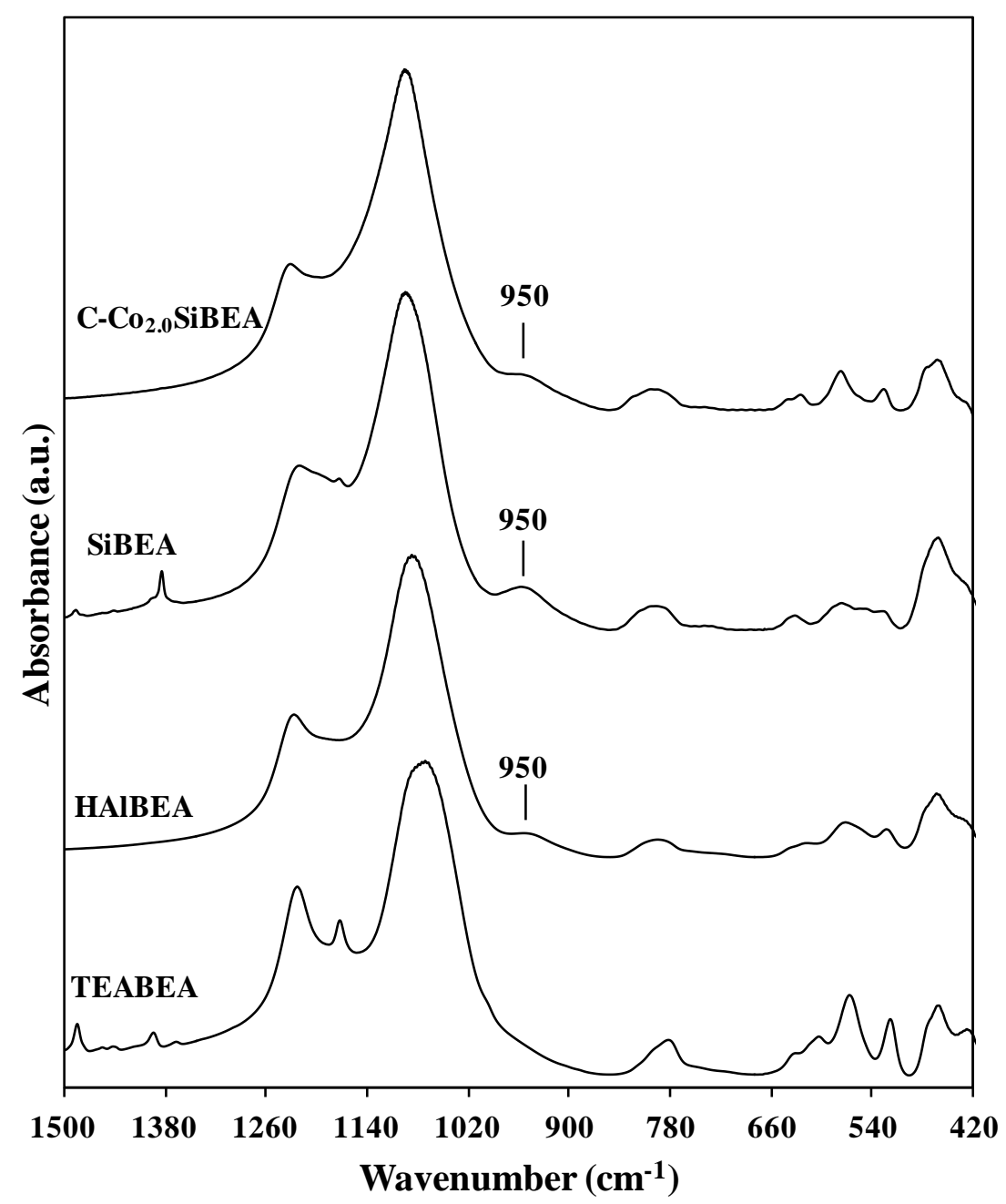

Figure 2 


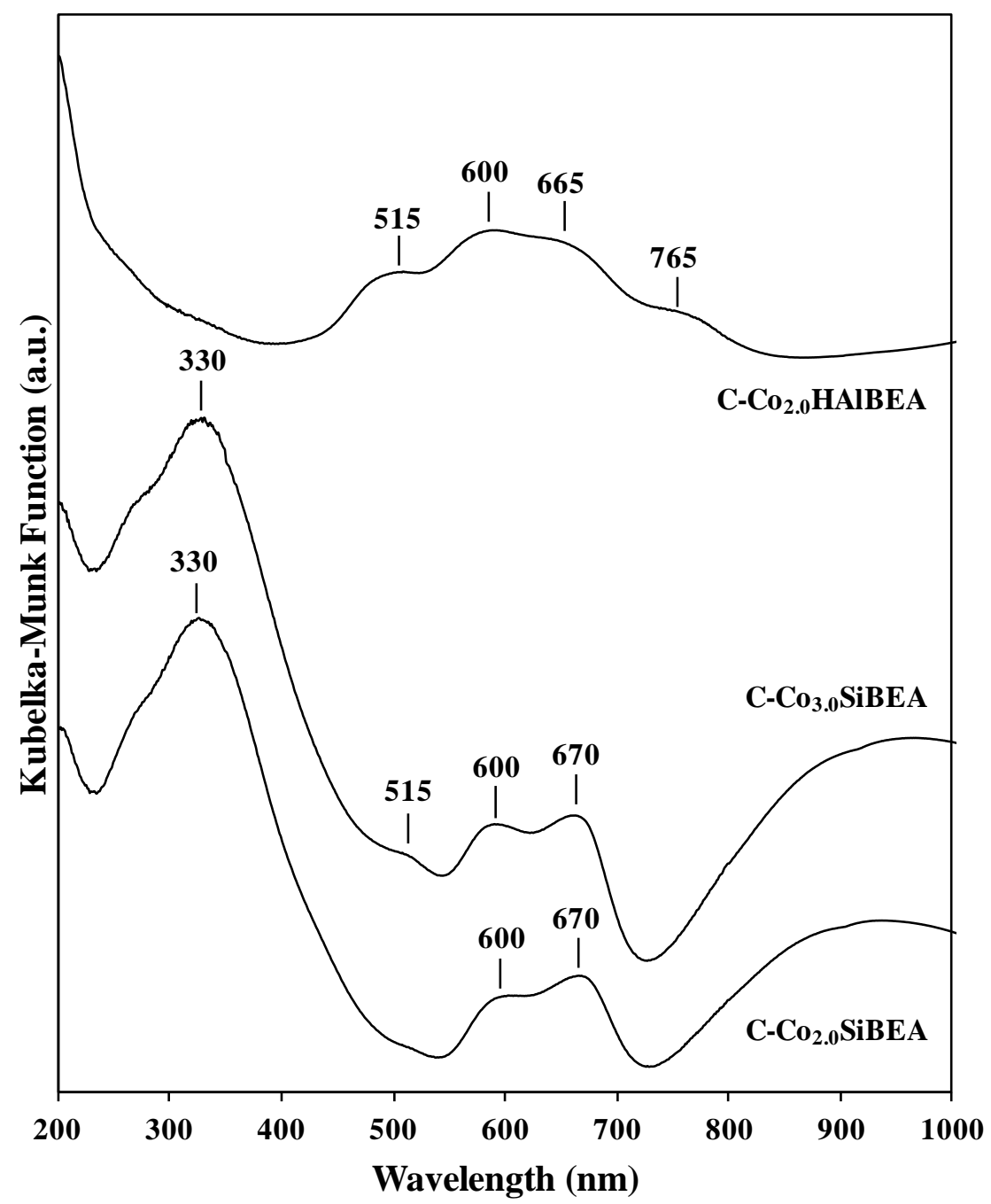

Figure 3 


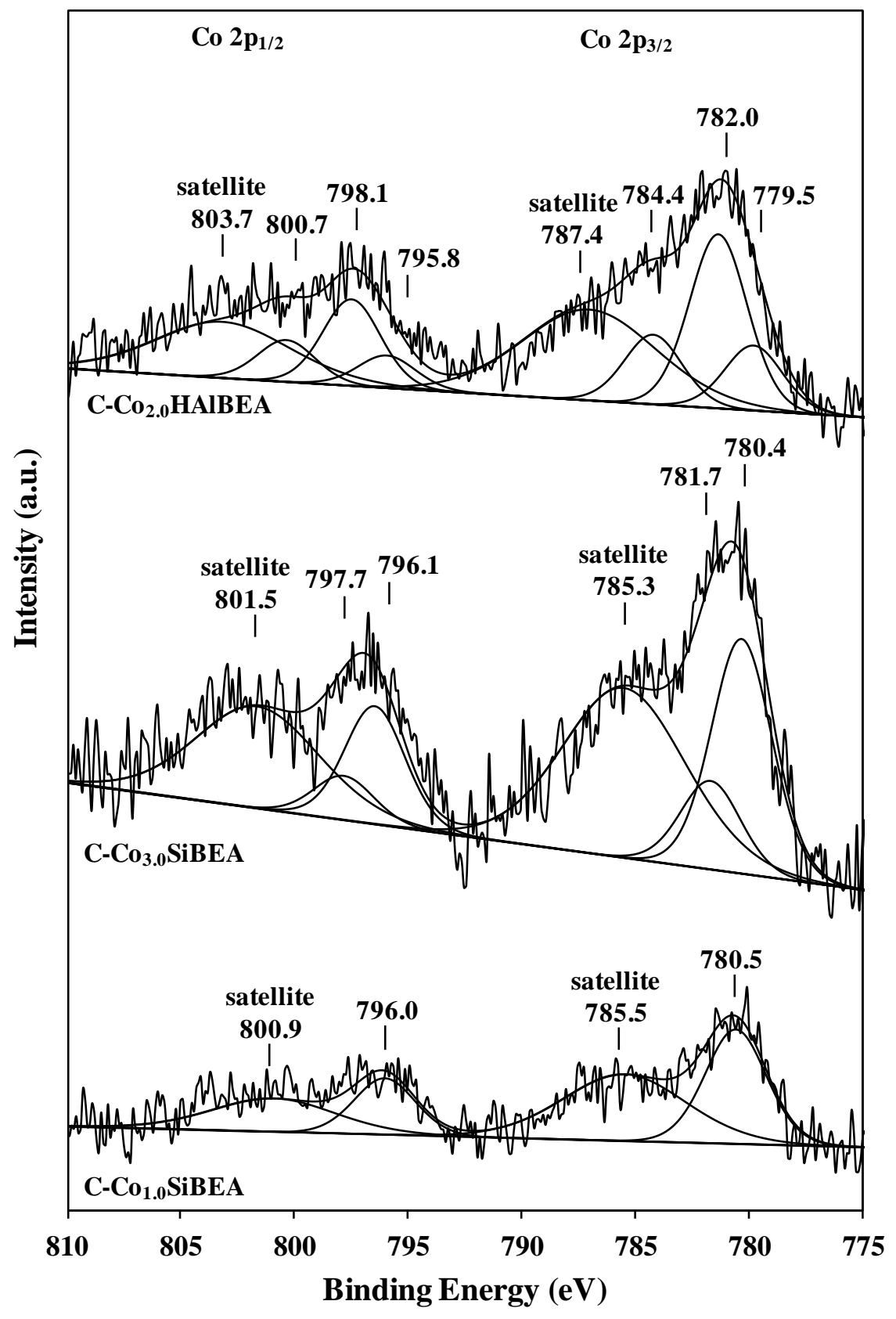

Figure 4 


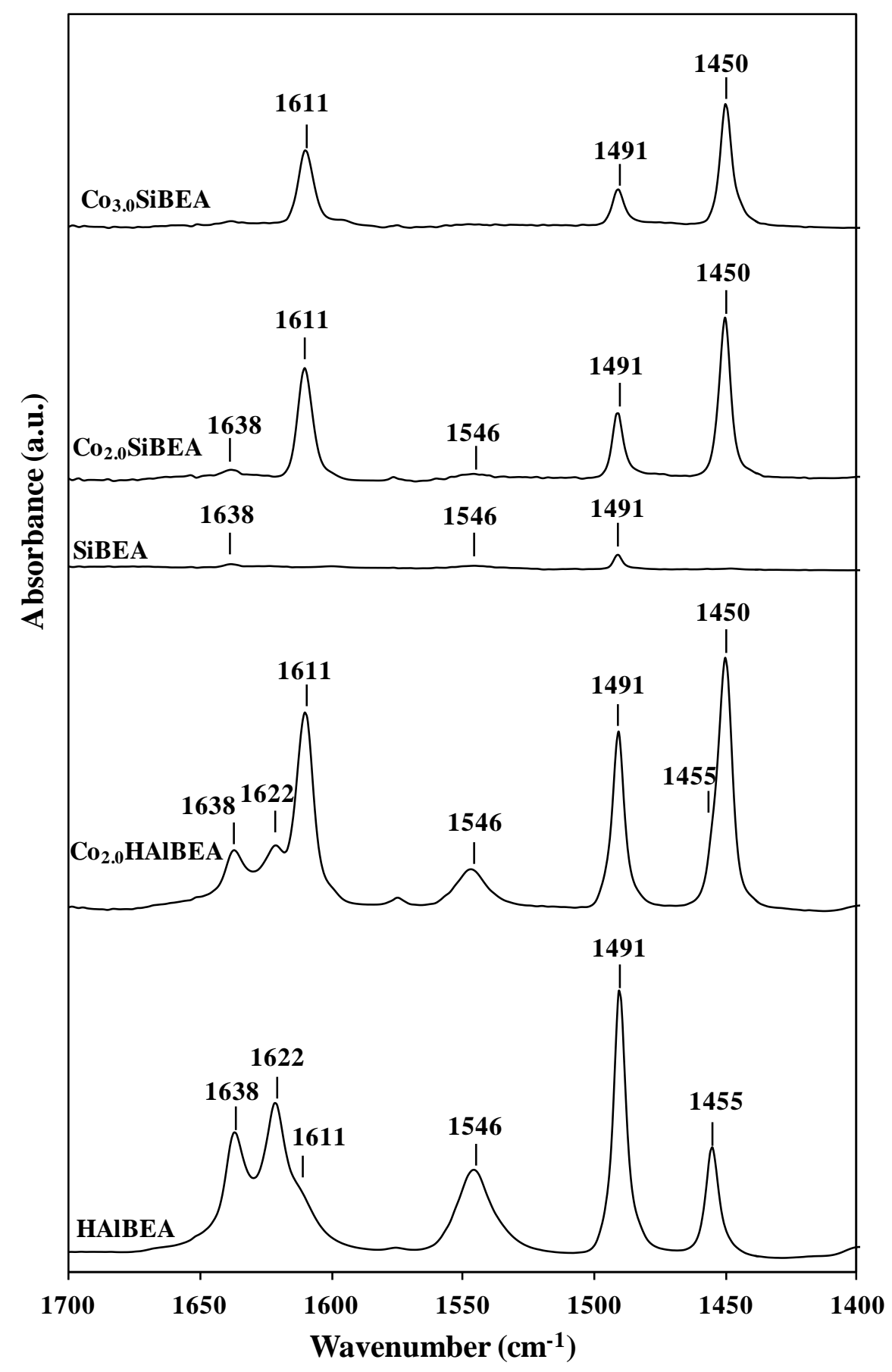

Figure 5 

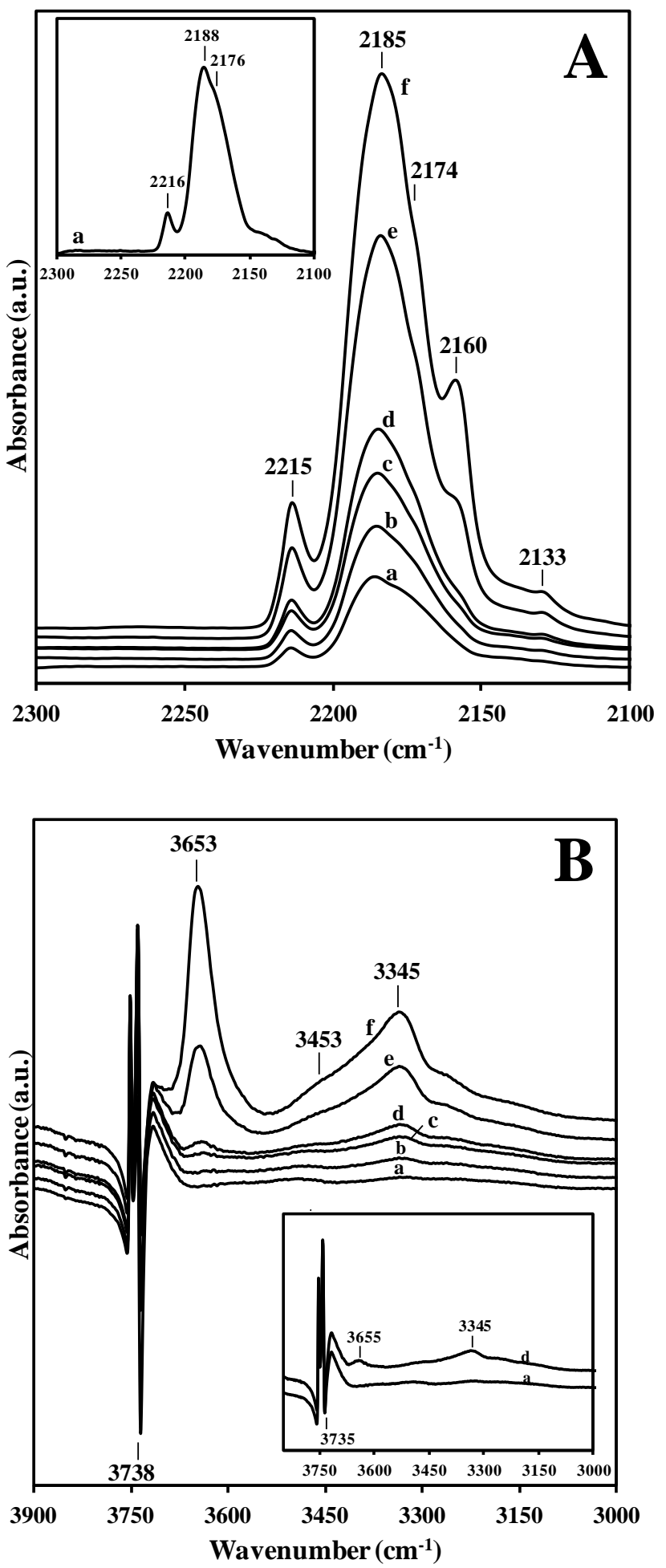

Figure 6 

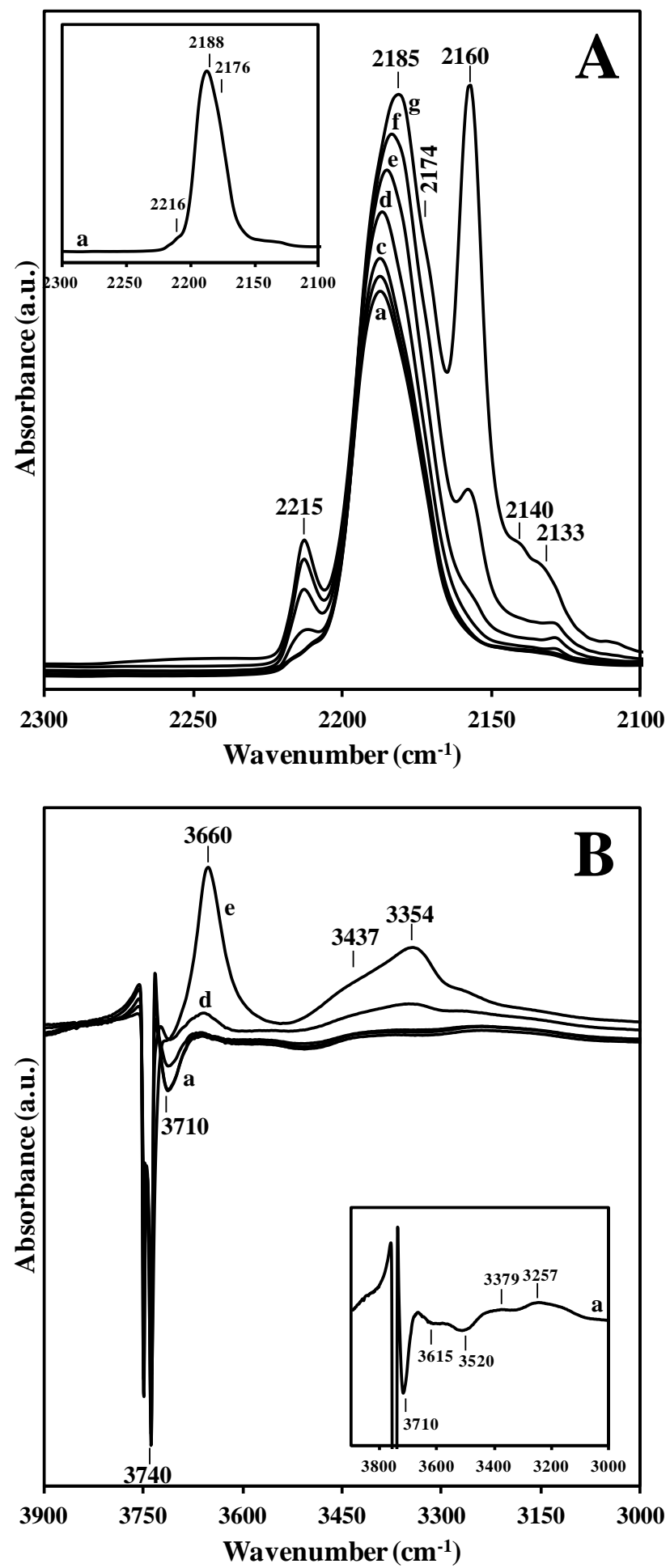

Figure 7 


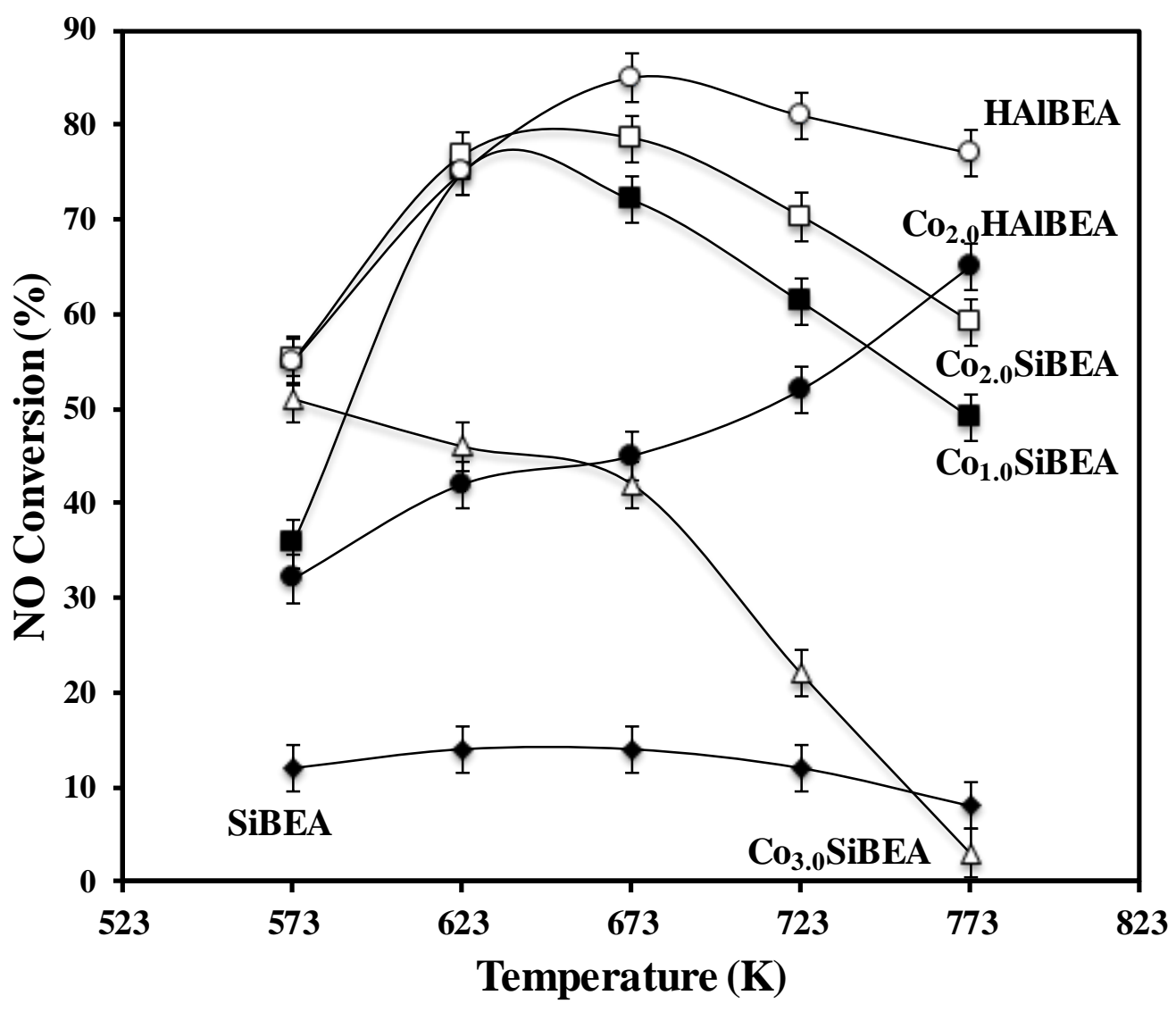

Figure 8 


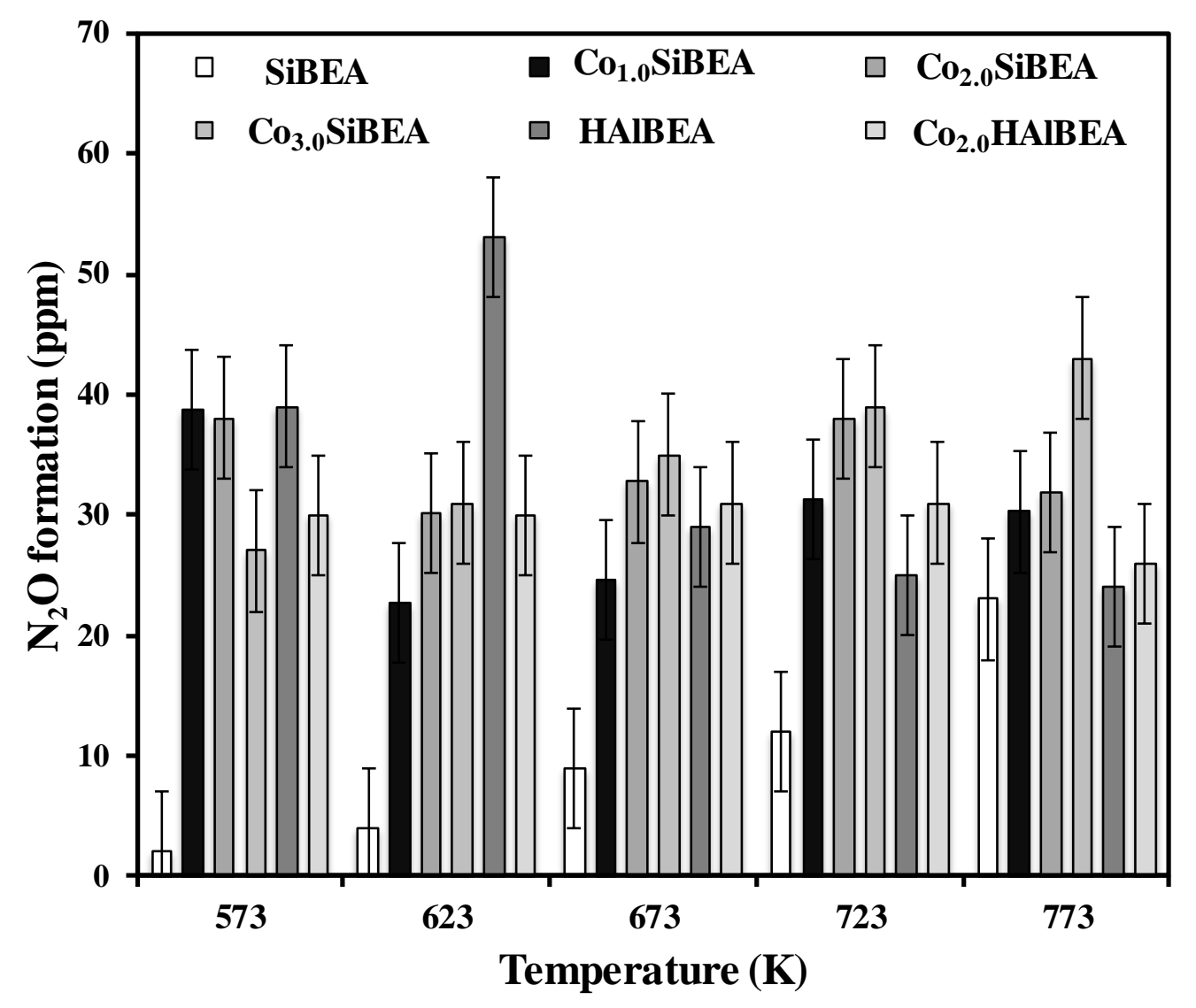

Figure 9 


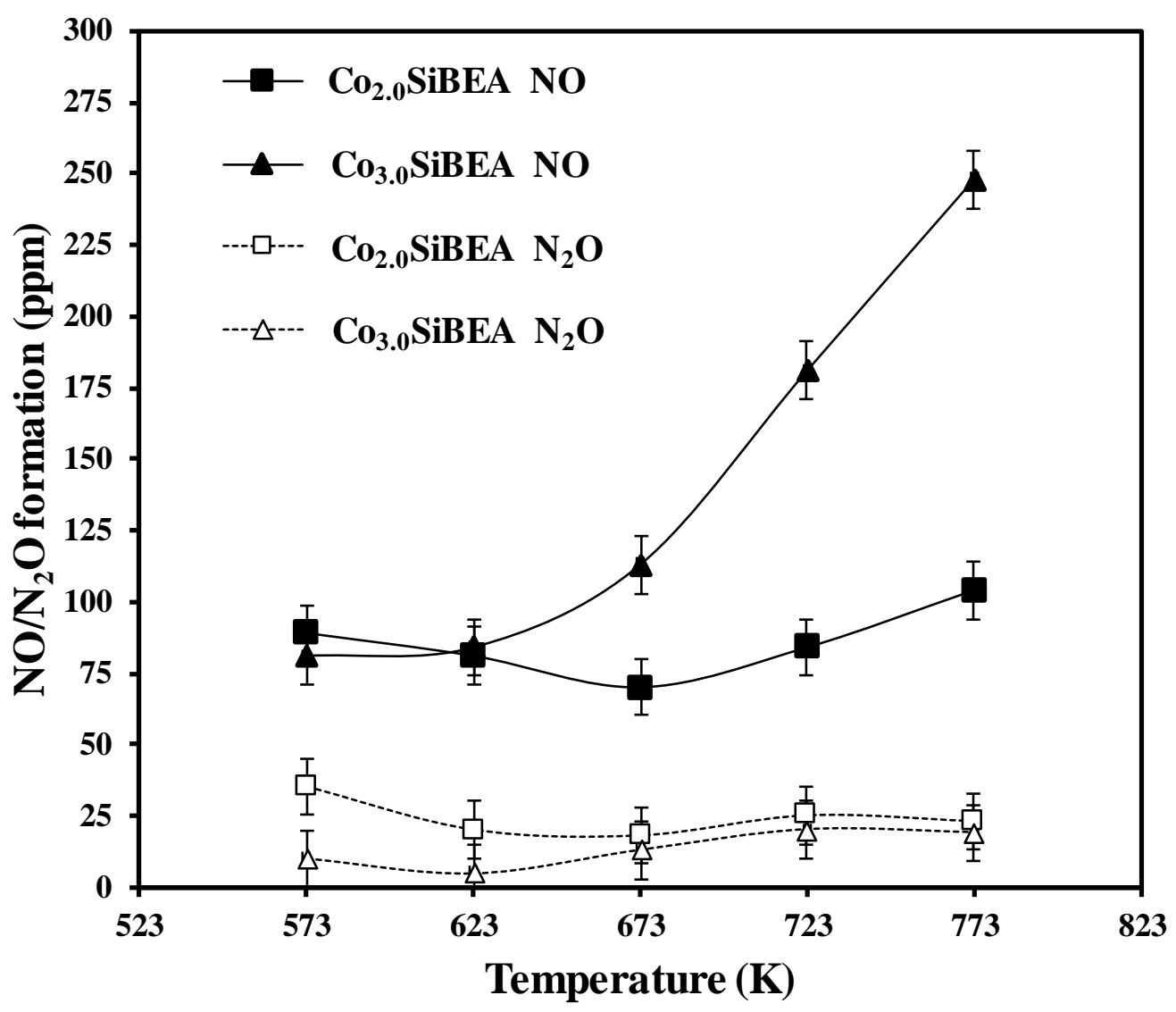

Figure 10 